(2) Open Access Full Text Article

REVIEW

\title{
Long-term treatment of patients with HIV-I: the role of atazanavir
}

This article was published in the following Dove Press journal:

HIVIAIDS - Research and Palliative Care

10 September 2010

Number of times this article has been viewed

\author{
Miguel Ángel Artacho' \\ Pablo Barreiro ${ }^{2}$ \\ José Vicente Fernández- \\ Montero ${ }^{2}$ \\ 'Department of Internal Medicine, \\ Hospital Universitario Gregorio \\ Marañón, Madrid, Spain; ${ }^{2}$ Department \\ of Infectious Diseases, Hospital \\ Carlos III, Madrid, Spain
}

Background: The introduction of highly-active antiretroviral therapy (HAART) remains a major milestone in the management of HIV-infected patients. Protease inhibitors (PI) are commonly used as part of triple combinations, given that to antiviral potency, better tolerance and convenience has been achieved in recent years.

Objective: To summarize and update evidence-based information about atazanavir (ATV) on initial, simplification, and rescue interventions in HIV patients.

Methods: Review of observational and randomized trials reported in medical conferences, peer-reviewed journals, and treatment guidelines.

Results: ATV is a second-generation PI, which has shown across studies potent antiviral activity and high genetic barrier, both in HAART-naïve patients or after virological failure. Indulgent metabolic profile, in terms of insulin glucose and lipid levels, adds value to this drug for the long-term management of HIV infection.

Keywords: atazanavir, HAART, protease inhibitors

\section{Introduction}

The availability of protease inhibitors (PI) has dramatically changed the natural history and treatment of HIV infection. This drug class became available in the mid 90s and allowed for the first time, as part of triple combinations, sustained suppression of HIV replication followed by immune restoration and prolonged AIDS-free survival. Nevertheless, first-generation PI have some disadvantages as compared with other drug classes later developed, such as non-nucleoside reverse transcriptase inhibitors (NNRTI) or integrase inhibitors (INSTI). ${ }^{1}$ PI require pharmacokinetic enhancement with ritonavir (RTV) to ensure potency and facilitate adherence. Low doses of RTV potently inhibit several cytochrome $\mathrm{P} 450$ isoenzymes, mainly CYP3A4, which are critical for the gastrointestinal and liver clearance of other PI. The net effect is greater plasma concentrations of the active PI, which allows twice or once daily dosing and significant reductions in pill burden. Poor gastrointestinal tolerance, metabolic abnormalities, and fat redistribution still penalize long-term use of first-generation PI.

Newer PI have been developed to overcome some of the limitations of older PI. Among these, ATV, marketed as Reyataz ${ }^{\circledR}$ (Bristol-Myers Squibb) since 2003, should be highlighted for its favorable lipid profile, once-daily dosing, low pill burden, and high genetic barrier to resistance. Furthermore, ATV may be administered without RTV enhancement or, when needed, at low doses not usually related with significant adverse effects. 


\section{Pharmacology}

\section{and pharmacokinetics of ATV}

ATV is an azapeptide inhibitor of the HIV-1 protease, with following chemical name:(3S, 8S,9S, 12S)-3,12bis (1,1-dimethylethyl)-8-hydroxy-4, 11 -dioxo9-(phenylmethyl)-6-((4-(2-pyridiny 1$)$ pheny 1$)$ methyl)-2,5,6,10,13-pentazatetradecanedioic acid dimethyl ester sulfate (Figure 1). The compound inhibits the virusspecific processing of viral Gag and Gag-Pol polyproteins of HIV-1 group M, subtypes A, B, C, D, AE, AG, F, G, and J, in infected cells thus preventing formation of mature virions. ${ }^{2}$

In some studies on PI-naïve patients, ${ }^{3,4}$ the concentration that inhibits $50 \%$ of viral replication (IC50) in the absence of human serum, ranged from $0.6 \mathrm{ng} / \mathrm{mL}$ to $5.7 \mathrm{ng} / \mathrm{mL}$. The presence of $40 \%$ human serum in cell cultures increased ATV IC50 by 2.7- to 3.6-fold, as found with other PIs. The adjusted IC50 for protein binding was estimated to range from 8 to $20 \mathrm{ng} / \mathrm{mL}$ against reference viral strains with a conventional cycle cell infection and the PhenoSense ${ }^{\mathrm{TM}}$ single assay (ViroLogic, Inc, South San Francisco, CA, USA), respectively. ${ }^{3}$

ATV is rapidly absorbed with a $\mathrm{C}_{\max }$ occurring after approximately $2.5 \mathrm{~h}$ post-dosing, demonstrating non-linear pharmacokinetics, a feature that allows once daily posology $y^{5,6}$ (Table 1). The extent of absorption is highly dependent on gastric $\mathrm{pH}$ and increases when taken together with food. ATV is highly bound to human serum proteins (up to $86 \%$ ), especially and in a similar proportion to alpha-1-acid glycoprotein and albumin. ATV is a substrate for P-glycoprotein (P-gp), an efflux transporter that will act to limit tissue compartment distribution. Like other PIs, ATV is extensively metabolized by the hepatic cytochrome P450, primarily by the CYP3A4 and CYP3A5 isoenzymes. ATV metabolites follow biliary and urinary excretion for $79 \%$ and $13 \%$ of the administered dose, respectively. Unchanged drug is found in feces and urine in proportions of $20 \%$ and $7 \%$ of the dose administered, respectively. Steady-state is achieved after 4 to 8 days of treatment, with a body accumulation of approximately 2.3-fold. Finally, ATV enters scarcely the cerebrospinal or semen compartments, although improves with RTV boosting. ${ }^{\text {? }}$

Addition of RTV at low doses (100 mg daily) to ATV at slightly lower doses (300 mg daily) results in an increase of ATV half-life, minimum $\left(\mathrm{C}_{\text {min }}\right)$ and maximum concentrations $\left(\mathrm{C}_{\max }\right)$, and area under the curve (AUC) as compared with ATV $400 \mathrm{mg}$ daily alone. A study involving 214 HIVinfected patients ${ }^{8}$ showed a large inter-individual variability in ATV disposition, which was associated with factors like prior exposure to RTV or nevirapine (NVP), as well as body weight.

There are scarce data on the use of ATV in pediatric patients and the optimal dosage has not been established. The phase I/II PATCG 1020A trial, involving 172 HIV-infected children with an age range of 1 to 17 years, studied ATV at a dose of $310 \mathrm{mg}$ per $\mathrm{m}^{2}$ of body surface, adjusted over 24 hours. AUC values showed great variability, which was particularly evident between younger and older patients. ${ }^{9}$

Although liver safety of ATV is proven, pharmacokinetics in patients with hepatic impairment remains an important issue given major liver metabolism of the drug. Though there are few data of ATV use in HIV-infected patients with severe

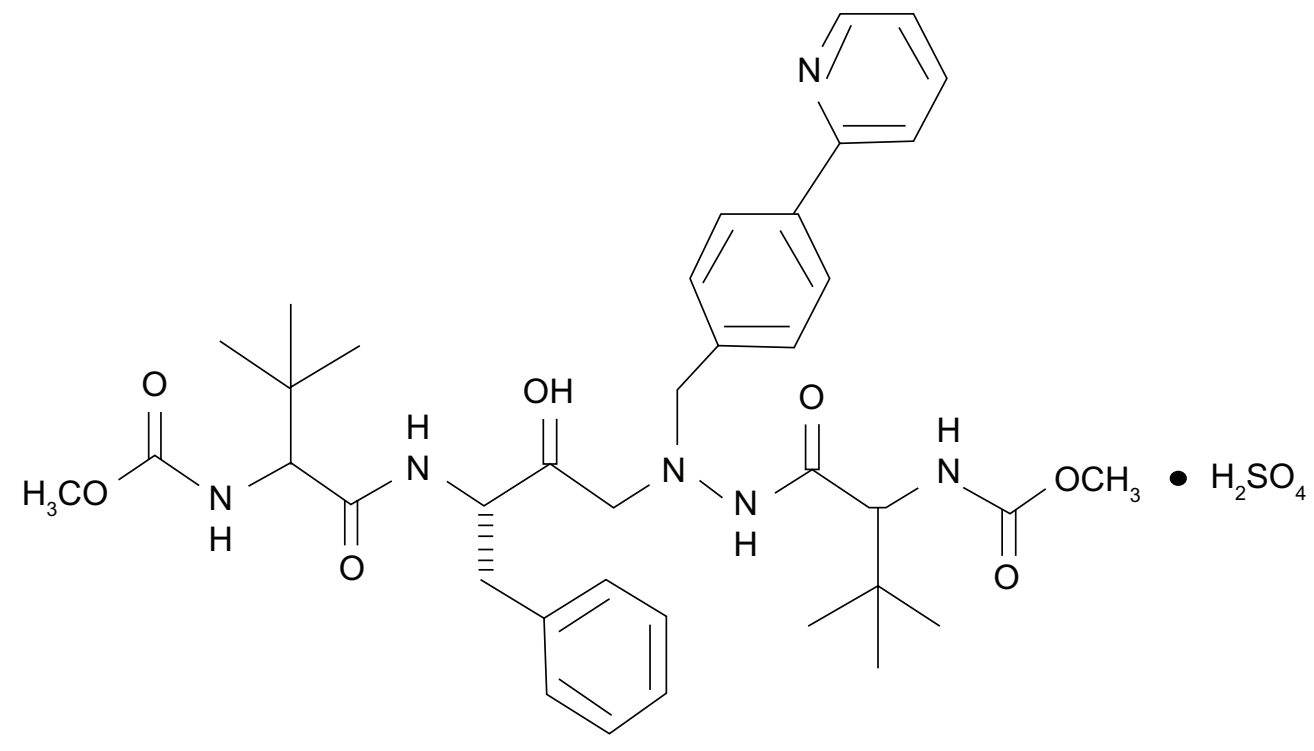

Figure I Chemical structure of atazanavir sulfate. 
Table I Pharmacokinetic parameters at steady state after atazanavir (ATV) $400 \mathrm{mg}$ once daily and after atazanavir (ATV) $300 \mathrm{mg}$ with ritonavir $100 \mathrm{mg}$ once daily with a light meal in HIVinfected patients ${ }^{2}$

\begin{tabular}{lll}
\hline & ATV $400 \mathbf{~ m g}$ & ATV/RTV 300/100 $\mathbf{~ m g}$ \\
\hline Bioavailability (\%) & 68 & Not available \\
Protein binding (\%) & 86 & 86 \\
Clh (L/h) & 25.2 & Not available \\
Clr of parent drug (\%) & 7 & Not available \\
$\mathrm{t}_{1 / 2}$, mean $\pm \mathrm{SD}(\mathrm{h})$ & $6.5 \pm 2.6$ & $8.6 \pm 2.3$ \\
$\mathrm{C}_{\text {max }}$, mean $\pm \mathrm{SD}(\mathrm{ng} / \mathrm{mL})$ & $3152 \pm 223 \mathrm{I}$ & $5233 \pm 3033$ \\
$\mathrm{~T}_{\text {max }}$, median $(\mathrm{h})$ & 2 & 3 \\
$\mathrm{C}_{\text {min }}$, mean $\pm \mathrm{SD}(\mathrm{ng} / \mathrm{mL})$ & $273 \pm 298$ & $862 \pm 838$ \\
AUC, mean $\pm \mathrm{SD}(\mathrm{ng} / \mathrm{mLh})$ & $22262 \pm 20159$ & $53761 \pm 35294$ \\
\hline
\end{tabular}

hepatic dysfunction, an increased exposure to ATV should be expected. In pharmacokinetic studies carried out in noninfected adults with moderate to severe hepatic impairment, AUC was increased in $42 \%$ after a single dose of ATV of $400 \mathrm{mg}$, compared with healthy volunteers. On the basis on these data, a dose reduction of ATV is advised for patients with moderate hepatic dysfunction. In contrast, in a study conducted in $58 \mathrm{HCV} / \mathrm{HIV}$-coinfected patients with compensated liver disease, ATV $\mathrm{C}_{\min }$ did not differ significantly between patients with and without cirrhosis. ${ }^{10}$

ATV pharmacokinetics has also been studied in patients with renal impairment. Doses of ATV of $400 \mathrm{mg}$ QD have been assessed in 20 adults with severe renal impairment, including a few in hemodialysis. The mean ATV $\mathrm{C}_{\max }$ was $9 \%$ lower, AUC was $19 \%$ higher, and $\mathrm{C}_{\min }$ was $96 \%$ higher in subjects with severe renal impairment not undergoing hemodialysis, than in subjects with normal renal function. When ATV was administered either prior to or following hemodialysis, the geometric means for $\mathrm{C}_{\max }, \mathrm{AUC}$, and $\mathrm{C}_{\text {min }}$ were approximately $25 \%$ to $43 \%$ lower compared to subjects with normal renal function. No dose adjustment is required in patients who are not undergoing hemodialysis, and such patients should receive the standard dose of $300 \mathrm{mg}$ per day of ATV with $100 \mathrm{mg}$ per day of RTV. ATV should not be administered in patients with end stage renal disease managed with hemodialysis. ${ }^{2}$

Some pharmacokinetic studies in pregnant women are available. In 12 HIV-infected women receiving boosted $\mathrm{ATV}^{11}$ the AUC and $\mathrm{C}_{\text {min }}$ in third trimester of pregnancy were approximately 40 and $21 \%$ lower, respectively, than in non-pregnant HIV-infected women. All individuals reaching delivery achieved plasma HIV-RNA $<50$ copies $/ \mathrm{mL}$ and all infants tested were HIV-negative and presented normal bilirubin levels through day 14 . Nevertheless, one newborn developed grade 3 hyperbilirubinemia at day 15. In another study ${ }^{12}$ total bilirubin concentrations in newborns were above normal limits at birth and day 3 , and three neonates had transient jaundice which did not require phototherapy. Data obtained in trials assessing other PI in pregnant women ${ }^{13}$ suggest a decrease in plasma exposure during the third trimester. Current guidelines ${ }^{14}$ consider ATV as an alternative regimen to first-line choice with lopinavir (LPV). No evidence of human teratogenicity has been communicated to date. Furthermore, ATV transplacental passage is low which favors fetal safety but may compromise vertical prophylaxis. The recommended dosage of ATV during pregnancy is $300 \mathrm{mg}$ QD, with $100 \mathrm{mg}$ of RTV. ATV plasma concentrations should be monitored throughout the pregnancy period to ensure levels greater than $150 \mathrm{ng} / \mathrm{mL}$, although no dose adjustment has yet been established.

ATV is a substrate and inhibitor of CYP3A, CYP2C8, UGT1A1, and P-gp. ${ }^{15}$ Therefore, administration of ATV and drugs primarily metabolized by these isoenzymes and/or substrates of P-gp may cause an increase in plasma concentrations of the concomitant drug, potentially enhancing or prolonging both their therapeutic and adverse effects. Due to afore mentioned inhibitory effect of RTV on CYP3A isoenzyme, the magnitude of drug interaction with boosted ATV may change. Drugs inducing CYP3A4 and/or P-gp metabolism, such as rifampin, may decrease ATV plasma concentrations and therefore compromise ATV therapeutic effect. Finally, drugs altering the gastric $\mathrm{pH}$ may affect ATV solubility and consequently its bioavailability. Use of proton pump inhibitors along with ATV should be avoided (Table 2).

\section{Antiviral efficacy}

ATV has shown its efficacy both in treatment-naïve and experienced patients, with a high genetic barrier, as found in several studies (Table 3). The Phase II studies BMS-AI424-007 and BMS-AI424-008. ${ }^{16,17}$ The AI424-034 study ${ }^{18}$ compared unboosted ATV (400 mg daily) with EFV in combination with zidovudine (AZT) plus lamivudine (3TC) as the nucleoside backbone. Probably due to recruitment of a significant number of patients with high plasma HIV-RNA concentrations ( $42 \%$ with $\geq 5 \log _{10}$ copies $/ \mathrm{mL}$ ) and low CD4 counts (median of 282 cells $/ \mu \mathrm{L}$ ), performance after 48 weeks was lower than expected, although comparable between groups $(70 \%$ and $64 \%$ of patients attained $<400$ HIV-RNA copies $/ \mathrm{mL}$ with ATV and EFV, respectively). Both regimens were also comparable with respect to the magnitude and rate of CD4 T-cell gains. EFV was associated with less favorable outcome 
Table 2 Main drug interactions with atazanavir (ATV) $)^{14}$

\begin{tabular}{|c|c|c|c|}
\hline Family & Drug & Effect on concentration & Recommendation \\
\hline Antiarrhytmics & $\begin{array}{l}\text { amiodarone, bepridil, } \\
\text { lidocaine, quinidine }\end{array}$ & $\uparrow$ antiarrhytmic & Caution is warranted,TDM recommended. \\
\hline Anticoagulants & warfarin & $\uparrow$ warfarin & Monitoring of INR is recommended. \\
\hline Anticonvulsants & $\begin{array}{l}\text { carbamazepine, } \\
\text { phenobarbital phenytoin }\end{array}$ & expected $\downarrow$ ATV & Use with caution. \\
\hline Antidepressants & $\begin{array}{l}\text { tricyclic antidepressants } \\
\text { trazodone }\end{array}$ & $\begin{array}{l}\uparrow \text { tricylcic antidepressants } \\
\uparrow \text { trazodone }\end{array}$ & $\begin{array}{l}\text { Use with caution, TDM is recommended. TDM is recommended } \\
\text { and lower trazodone doses should be used. }\end{array}$ \\
\hline Antifungals & itraconazole, ketoconazole & $\begin{array}{l}\uparrow \text { itraconazole, ketoconazole } \\
\text { (ATV 400) }\end{array}$ & $\begin{array}{l}\text { If ATV is used with RTV, itraconazole or ketoconazole doses of } \\
>200 \mathrm{mg} / \text { day should be used with caution. }\end{array}$ \\
\hline Antihistamines & astemizole, terfenadine & no data available & $\begin{array}{l}\text { ATV/RTV should not be used in combination with drugs that } \\
\text { are substrates of the CYP3A4 and have narrow therapeutic } \\
\text { windows, such as terfenadine and astemizole. }\end{array}$ \\
\hline Antimicrobial agents & clarithromycin & $\begin{array}{l}\uparrow \text { clarithromycin } \\
\downarrow \text { I4-OH-clarithromycin } \\
\uparrow \text { ATV concentrations }\end{array}$ & $\begin{array}{l}\text { Dose reductions by } 50 \% \text { should be considered. Combination } \\
\text { with boosted ATV has not yet been studied. }\end{array}$ \\
\hline Antimycobacterials & $\begin{array}{l}\text { rifabutin } \\
\text { rifampicin }\end{array}$ & $\begin{array}{l}\uparrow \text { rifabutin } \\
\text { severe } \downarrow \text { ATV }\end{array}$ & $\begin{array}{l}\text { Reduce rifabutin dose to } 150 \mathrm{mg} \text { every other day or to } 3 \mathrm{x} / \text { week. } \\
\text { Contraindicated. }\end{array}$ \\
\hline \multirow[t]{3}{*}{ Antiretroviral agents } & $\begin{array}{l}\text { NRTIs: } \\
\text { didanosine (buffered } \\
\text { formulation) } \\
\text { tenofovir } \\
\text { NNRTls: } \\
\text { efavirenz } \\
\text { nevirapine } \\
\text { etravirine }\end{array}$ & $\begin{array}{l}\downarrow \text { ATV } \\
\text { expected } \downarrow \text { ATV } \\
\uparrow \text { etravirine, } \downarrow \text { ATV }\end{array}$ & $\begin{array}{l}\text { The recommended dose in treatment-naïe patients is ATV/ } \\
\text { RTV } 300 / 100 \mathrm{mg} \text {. No recommendation has been established in } \\
\text { treatment-experienced patients. } \\
\text { Coadministration is not recommended. } \\
\text { ATV should be boosted with RTV. }\end{array}$ \\
\hline & $\begin{array}{l}\text { Pls: } \\
\text { indinavir } \\
\text { saquinavir } \\
\text { (soft gelatin capsules) } \\
\text { tipranavir } \\
\text { INSTIs: }\end{array}$ & $\begin{array}{l}\uparrow \text { saquinavir } \\
\text { expected } \downarrow \text { ATV }\end{array}$ & $\begin{array}{l}\text { Contraindicated due to synergistic effect on hyperbilžrubinemia. } \\
\text { Appropriate recommendations for this combination have not } \\
\text { been established.TDM is recommended. } \\
\text { ATV and tipranavir should not be coadministered. }\end{array}$ \\
\hline & raltegravir & $\uparrow$ raltegravir & The clinical relevance of these data is unknown. \\
\hline $\begin{array}{l}\text { Calcium channel } \\
\text { blockers }\end{array}$ & diltiazem & $\begin{array}{l}\uparrow \text { diltiazem and } \\
\text { desacetyl-diltiazem }\end{array}$ & $\begin{array}{l}\text { Caution is warranted. } 50 \% \text { dose reduction of diltiazem should be } \\
\text { considered. }\end{array}$ \\
\hline & $\begin{array}{l}\text { felodipine, nifedipine, } \\
\text { nicardipine, verapamil }\end{array}$ & $\begin{array}{l}\uparrow \text { felodipine, nifedipine, } \\
\text { nicardipine, verapamil }\end{array}$ & $\begin{array}{l}\text { Caution is warranted and ECG monitoring is recommended. } \\
\text { Dose titration should be considered. }\end{array}$ \\
\hline Corticoesteroids & fluticasone & $\uparrow$ fluticasone & Caution is warranted. \\
\hline Ergot derivatives & $\begin{array}{l}\text { dihydroergotamine, } \\
\text { ergotamine, ergonovine, } \\
\text { methylergonovine }\end{array}$ & $\uparrow$ ergot derivatives & Contraindicated. \\
\hline \multirow[t]{3}{*}{$\begin{array}{l}\text { Acid suppressive } \\
\text { therapy }\end{array}$} & antiacids & $\downarrow$ ATV & $\begin{array}{l}\text { ATV should be administered } 2 \mathrm{~h} \text { before or } \mathrm{I} \mathrm{h} \text { after intake of } \\
\text { antacids. }\end{array}$ \\
\hline & $\mathrm{H}_{2}$ receptor antagonists & $\downarrow$ ATV & $\begin{array}{l}\mathrm{H}_{2} \text { receptor antagonist should not exceed a } 40 \mathrm{mg} \text { dose } \\
\text { equivalent of famotidine twice daily and ATV should be } \\
\text { administered with } \mathrm{RTV} \text { simultaneously, with, and/or at least } 10 \mathrm{~h} \\
\text { after the dose of the } \mathrm{H}_{2} \text {-receptor antagonist. }\end{array}$ \\
\hline & proton pump inhbitors & $\downarrow$ ATV & $\begin{array}{l}\text { ATV/RTV is recommended. Proton-pump inhibitor dose should } \\
\text { not exceed a } 20 \text { mg dose equivalent of omeprazole and must } \\
\text { be taken approximately } 12 \mathrm{~h} \text { prior to ATV/RTV in antiretroviral- } \\
\text { naïve patients. Proton-pump inhibitors should not be used in } \\
\text { treatment-experienced patients. }\end{array}$ \\
\hline Herbal products & worth & expected $\downarrow$ ATV & Contraindicated. \\
\hline $\begin{array}{l}\text { HMG-CoA reductase } \\
\text { Inhbitors }\end{array}$ & lovastatin, simvastatin & $\uparrow$ lovastatin, simvastatin & Contraindicated. \\
\hline
\end{tabular}


Table 2 (Continued)

\begin{tabular}{|c|c|c|c|}
\hline Family & Drug & Effect on concentration & Recommendation \\
\hline & $\begin{array}{l}\text { atorvastatin, } \\
\text { rosuvastatin }\end{array}$ & $\begin{array}{l}\uparrow \text { atorvastatin, } \\
\text { rosuvastatin }\end{array}$ & $\begin{array}{l}\text { Use the lowest possible dose of atorvastatin or rosuvastatin } \\
\text { with careful monitoring or consider other HMG-CoA reductase } \\
\text { inhibitor such as pravastatin or fluvastatin. }\end{array}$ \\
\hline Immuno-suppressants & $\begin{array}{l}\text { cyclosporine A, sirolimus, } \\
\text { tacrolimus }\end{array}$ & $\uparrow$ immunosuppressants & TDM is recommended. \\
\hline Neuroleptics & pimozide & $\uparrow$ pimozide & Contraindicated. \\
\hline Oral contraceptives & $\begin{array}{l}\text { ethinyl estradiol, } \\
\text { norethindrone }\end{array}$ & $\downarrow \uparrow$ oral contraceptives & $\begin{array}{l}\text { Due to possible alteration of oral contraceptive concentrations, } \\
\text { alternative/additional contraceptive measures should be used } \\
\text { when coadministered with ATV or ATV/RTV. }\end{array}$ \\
\hline PDE5 inhibitors & $\begin{array}{l}\text { sildenafil, tadalafil, } \\
\text { vardenafil }\end{array}$ & $\begin{array}{l}\uparrow \text { sildenafil, tadalafil, } \\
\text { vardenafil }\end{array}$ & $\begin{array}{l}\text { Do not exceed } 25 \mathrm{mg} \text { of sildenafil in } 48 \mathrm{~h}, 10 \mathrm{mg} \text { of taldalafil in } \\
72 \mathrm{~h} \text { or } 2.5 \mathrm{mg} \text { of vardenafil in } 72 \mathrm{~h} \text {. }\end{array}$ \\
\hline
\end{tabular}

Abbreviations: NRTI, nucleoside reverse transcriptase inhibitor; NNRTI, non-nucleoside reverse transcriptase inhibitor; PI, protease inhibitor; INSTI, integrase inhibitor; ATV, atazanavir; RTV, ritonavir; TDM, Therapeutic drug monitoring; INR, international normalized ratio; ECG, electrocardiogram.

in lipids (triglycerides and total LDL and HDL cholesterol) as compared with ATV. No significant variations in glucose metabolism were noticed in either group, although patients on EFV tended to show slight increases in fasting insulin levels.

The AI424-089 study, ${ }^{19}$ a randomized, multicenter, 96-week study, compared the efficacy and safety of boosted vs unboosted ATV in drug-naïve patients. Although overall efficacy results were comparable, rates of response were higher and emergence of PI resistance mutations lower in subjects on ATV plus RTV than with ATV alone. Concerns on a limited potency of unboosted ATV have been noted in several antiretroviral treatment guidelines, in which ATV alone is only recorded as an alternative option only for PI-naïve patients, or in simplification strategies. Use of tenofovir (TDF) always require boosted ATV due to lower PI exposure, unless ATV plasma levels $>150 \mathrm{ng} / \mathrm{mL}$ were confirmed under ATV alone.
The CASTLE trial, ${ }^{20}$ an open-label international noninferiority study, randomly assigned 883 treatment-naïve patients to receive either boosted ATV or LPV at standard doses, in combination with a fixed dose of tenofovir plus emtricitabine. After 48 weeks, plasma HIV-RNA $<50$ copies/ $\mathrm{mL}$ was attained at similar rates in both arms $(78 \%$ and $76 \%$, respectively) and CD4 gains were also comparable. Serious adverse events occurred in $12 \%$ of patients in the ATV group and in $10 \%$ of patients in the LPV group. However, a better lipid profile was observed in patients receiving ATV as compared with LPV. Moreover, gastrointestinal side effects were more common in the LPV group, whereas those receiving ATV were more likely to experience jaundice. Both treatments, however, were in general very well tolerated (Figure 2). The 96-weeks ${ }^{21}$ extension analysis confirmed that ATV was superior to LPV in terms of antiviral efficacy. In an intention-to-treat (ITT) analysis, $74 \%$ of patients in the ATV arm achieved HIV-RNA $<50$ copies/mL, compared

Table 3 Different genotypic resistance scores for atazanavir (boosted or unboosted) in relationship to clinical responses

\begin{tabular}{|c|c|c|c|}
\hline Source & Atazanavir & Protease mutations & Clinical cut-off \\
\hline Colonno et $\mathrm{al}^{3}$ & Unboosted & $\begin{array}{l}\mathrm{LIOF} / \mathrm{I} / \mathrm{V}, \mathrm{K} 20 \mathrm{I} / \mathrm{M} / \mathrm{R}, \mathrm{L} 24 \mathrm{I}, \mathrm{L} 33 \mathrm{~F} / \mathrm{I} / \mathrm{V}, \mathrm{M} 36 \mathrm{I} / \mathrm{L} / \mathrm{V}, \mathrm{M} 46 \mathrm{I} / \mathrm{L}, \mathrm{G} 48 \mathrm{~V} \text {, } \\
\mathrm{I54L/V}, \mathrm{L} 63 \mathrm{P}, \mathrm{A} 7 \mathrm{II} / \mathrm{V} / \mathrm{T}, \mathrm{G} 73 \mathrm{~A} / \mathrm{C} / \mathrm{S} / \mathrm{T}, \mathrm{V} 82 \mathrm{~A} / \mathrm{F} / \mathrm{T} / \mathrm{S}, \mathrm{I84V} \text {, } \\
\mathrm{L} 90 \mathrm{M} \text {, or the presence of I50L alone }\end{array}$ & $<$ versus $\geq 4$ \\
\hline $\begin{array}{l}\text { ANRS } 2004 \\
\text { www.sante.gouv.fr }\end{array}$ & Boosted & $\begin{array}{l}\mathrm{LIOF} / \mathrm{I} / \mathrm{V}, \mathrm{K} 20 \mathrm{I} / \mathrm{M} / \mathrm{R}, \mathrm{L} 24 \mathrm{I}, \mathrm{L} 33 \mathrm{~F} / \mathrm{I} / \mathrm{V}, \mathrm{M} 36 \mathrm{I} / \mathrm{L} / \mathrm{V}, \mathrm{M} 46 \mathrm{I} / \mathrm{L}, \mathrm{G} 48 \mathrm{~V} \text {, } \\
\mathrm{I54L/V}, \mathrm{L} 63 \mathrm{P}, \mathrm{A} 7 \mathrm{II} / \mathrm{V} / \mathrm{T}, \mathrm{G} 73 \mathrm{~A} / \mathrm{C} / \mathrm{S} / \mathrm{T}, \mathrm{V} 82 \mathrm{~A} / \mathrm{F} / \mathrm{T} / \mathrm{S}, \mathrm{I84V} \text {, } \\
\mathrm{L} 90 \mathrm{M} \text {, or the presence of I50L alone }\end{array}$ & $<$ versus $\geq 6$ \\
\hline ANRS $2005^{39}$ & Boosted & $\begin{array}{l}\mathrm{LIOF} / \mathrm{I} / \mathrm{V}, \mathrm{GI} 6 \mathrm{E}, \mathrm{L} 33 \mathrm{~F} / \mathrm{I} / \mathrm{V}, \mathrm{M} 46 \mathrm{I} / \mathrm{L}, \mathrm{D} 60 \mathrm{E}, 184 \mathrm{~V} \\
185 \mathrm{~V}, \mathrm{~L} 90 \mathrm{M} \text {, or the presence of I50L alone }\end{array}$ & $<$ versus $\geq 3$ \\
\hline Pellegrin et $\mathrm{al}^{40}$ & Boosted & $\begin{array}{l}\mathrm{LI} \text { OF/I/V, K20I/M/R, L24I, M46I/L, I54L/V, } \\
\text { Q58E, L63P, A7II/V/T, G73A/C/S/T, V77I, } \\
\text { V82A/F/T/S, I84V, L90M, or the presence of I50L alone }\end{array}$ & $<$ versus $\geq 5$ \\
\hline Bertoli et $\mathrm{al}^{41}$ & Unboosted & $\begin{array}{l}\mathrm{L} 10 \mathrm{C} / \mathrm{I} / \mathrm{V}, \mathrm{V} 32 \mathrm{I}, \mathrm{E} 34 \mathrm{Q}, \mathrm{M} 46 \mathrm{I} / \mathrm{L}, \mathrm{F} 53 \mathrm{~L}, \mathrm{I5} 4 \mathrm{~A} / \mathrm{M} / \mathrm{V}, \mathrm{V} 82 \mathrm{~A} / \mathrm{F} / \mathrm{I} / \mathrm{T} \text {, } \\
\mathrm{I84V}, \mathrm{II} \mathrm{E} / \mathrm{G} / \mathrm{L} / \mathrm{V}, \mathrm{H} 69 \mathrm{~K} / \mathrm{M} / \mathrm{N} / \mathrm{Q} / \mathrm{R} / \mathrm{T} / \mathrm{Y}, \mathrm{I72M} / \mathrm{T} / \mathrm{V}\end{array}$ & $<$ versus $\geq 4$ \\
\hline Bertoli et $\mathrm{al}^{41}$ & Boosted & $\begin{array}{l}\text { GI6E, V32I, K20I/M/R/T/V, L33F/I/V, F53L/Y, I64L/M/V, } \\
\text { A7II/T/V, I85V, I93L/M }\end{array}$ & $<$ versus $\geq 3$ \\
\hline
\end{tabular}




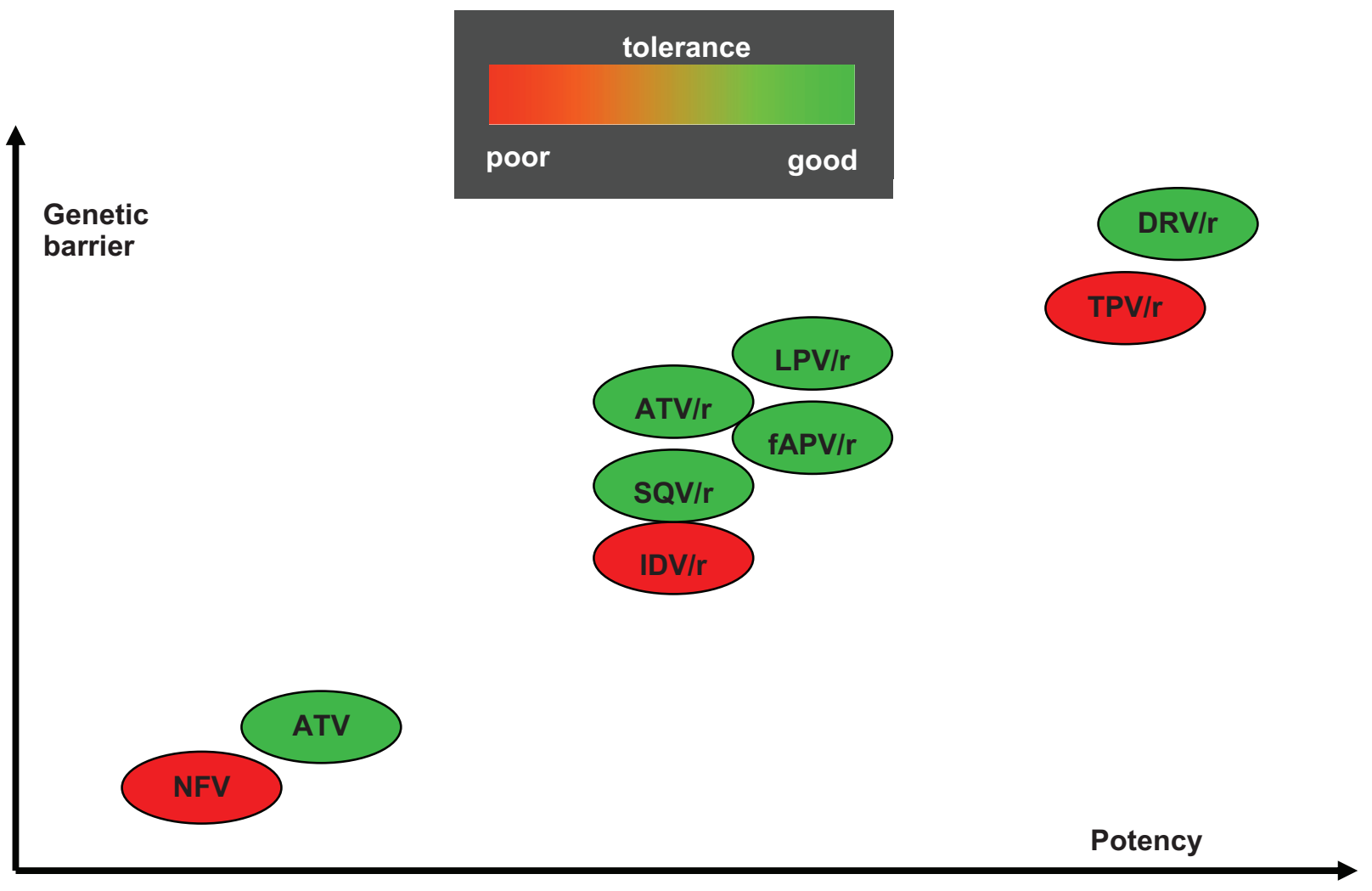

Figure 2 Potency and resistance genetic barrier of distinct protease inhibitors.

with $68 \%$ in the LPV group $(P<0.05)$. This superiority was also found when stratifying patients according to high $(>100,000$ copies $/ \mathrm{mL})$ or low $(<100,000$ copies $/ \mathrm{mL})$ baseline HIV-RNA levels. There were no significant differences among groups when comparing the CD4 cell count increase from baseline to 96 weeks (difference of 221 cells/ $\mathrm{mL} ; 95 \% \mathrm{CI},-43$ to 1 ). Adherence and safety profiles were similar in both groups in the extended analysis. Virological failures due to resistance were scarce and appeared in similar proportions in both groups, $6 \%$ and $7 \%$ in the ATV and LPV arms, respectively. The overall incidence of Grades 2-4 treatment-related adverse events was $30 \%$ and $32 \%$ in those patients on the ATV and LPV regimens, respectively. While gastrointestinal side effects were more common in the LPV group, hepatobiliary adverse events, namely jaundice and hyperbilirubinemia, were more frequent in the ATV group. Only 3 patients discontinued ATV therapy due to such events, none of them between weeks 48 and 96 .

Altogether these studies support the use of once-daily boosted ATV as a good first-line treatment option.

Recently, the results of ACTG 5202 trial $^{22}$ have become available. This trial, involving 1,857 HIV treatmentnaïve patients, assessed the efficacy of EFV and boosted ATV, combined with either TDF plus FTC or abacavir
(ABC) plus lamivudine (3TC) with a follow-up period of 96 weeks. In terms of time to loss of virological response (TLOVR), no significant differences were found between ATV and EFV regardless nucleoside combination (HR 1.13 [95\% CI, 0.82-1.56] with ABC/3TC and HR 1.01 [95\% CI, 0.7-1.46] with FTC/TDF). The combination of ABC/3TC plus ATV was associated with a longer time to regimen modification. Drug resistance rate was significantly lower in the ATV group when compared with EFV, regardless of nucleoside combination. ATV showed when combined with TDF/FTC a greater increase in CD4 cell count. Other trials comparing boosted ATV with NVP such as ArTEN ${ }^{23}$ and NEwArT as first-line therapy are ongoing.

RTV-boosted ATV has also been assessed as salvage therapy. The AI424-009 study ${ }^{24}$ was a randomized, multicentre, pilot trial that compared the safety and efficacy of SQV 1,200 mg QD plus ATV $400 \mathrm{mg}$ or $600 \mathrm{mg}$ QD vs RTV boosted SQV 400/400 mg BID. At 48 weeks, the dual PI regimens were as effective and well tolerated as RTV plus SQV. There were fewer discontinuations caused by adverse events in the ATV plus SQV groups ( $9 \%$ and $11 \%$, respectively) than in the RTV plus SQV group (30\%). Moreover, ATV groups showed significantly lower increase in lipids as compared with the SQV plus RTV group (1\% vs $10 \%$ in total 
cholesterol, -0.6 vs $+23.2 \%$ in LDL-cholesterol, and -4.8 vs $+93 \%$ in triglyceride levels).

In the AI424-043 study, ${ }^{25}$ patients who had failed at least one PI were rescued with unboosted ATV versus boosted LPV. The LPV arm resulted in a significantly greater reduction in plasma HIV-RNA than the ATV arm. Likewise, a greater $\mathrm{CD}^{+} \mathrm{T}$-cell gain was seen with LPV than ATV (+169 vs +112 cells/ $\mu \mathrm{L})$. However, whereas LPV increased lipid levels and induced insulin resistance, these parameters remained stable in the ATV arm.

Finally, the AI424-045 study ${ }^{26}$ compared boosted ATV with boosted LPV in patients who had failed at least two triple regimens. Approximately $40 \%$ of patients harboured $\geq 4$ nucleoside-associated resistance mutations and more than one third harboured $\geq 4$ PI resistance mutations. In the intention-to-treat analysis at 96 weeks, ${ }^{27}$ similar virological efficacy was demonstrated for ATV and LPV arms, with 44\% vs $46 \%$ of patients achieving $<400$ HIV-RNA copies $/ \mathrm{mL}$, respectively. Moreover, CD4 gains were comparable (+160 and +142 cells $/ \mu \mathrm{L}$, respectively). Although response rates were similar when fewer than four PI resistance mutations were present at baseline, LPV was slightly superior to ATV in patients with more than three PI resistance mutations. Conversely, the ATV arm benefited from less frequent gastrointestinal disturbances and significant reductions in total and LDL cholesterol, and triglyceride levels. The main drawback was that grade 3-4 hyperbilirubinemia developed in $53 \%$ of patients on ATV.

ATV has also been studied in several simplification trials. In the SLOAT study, ${ }^{28} \mathrm{HIV}$ patients with undetectable plasma HIV-RNA for longer than 24 weeks while under boosted LPV were randomized to continue on the same therapy or switch to boosted (in those on TDF) or unboosted ATV. The rate of virological failures at 48 weeks did not differ between groups. A significant reduction was seen in median total cholesterol and triglycerides in the ATV switch group, whereas no significant changes occurred in the control LPV arm. Greater reductions in total cholesterol and triglycerides were seen in patients switched to unboosted ATV.

The $\mathrm{SWAN}^{29}$ study was a 48 -week, open-label, prospective trial involving HIV patients with virologic suppression who were receiving stable PI-based regimens, with or without RTV. Again, patients were randomized 2:1 to boosted or unboosted ATV, depending on TDF use, or to continue on their prior PI. After 48 weeks, patients switched to ATV showed significantly lower total cholesterol, fasting triglycerides, and non-HDL cholesterol than patients in the comparator PI group. For patients with prior exposure to RTV-boosted PI regimens, the two treatment groups had comparable rates of virologic rebound. In contrast, significantly lower rebound rates were recognized for ATV vs comparator PI groups in the subset of patients with prior exposure to unboosted PI. A limitation of this study was that nearly half of the study participants entered the trial receiving obsolete unboosted PI modalities, and most of them switched to unboosted ATV, which is not the current standard of care.

Finally, boosted ATV has also been assessed as monotherapy. The ACTG 5201 study $^{30}$ was a prospective pilot trial with 34 HIV adults with virological suppression for $\geq 48$ weeks receiving their first PI regimen. All participants switched to boosted ATV at entry and discontinued the nucleoside analogue backbone after 6 weeks. Three participants (9\%) experienced virologic failure at weeks 12 , 14, and 20 after simplification without emergence of any PI resistance mutation. Plasma ATV concentrations at failure were low or below detection in two out of three subjects. The authors concluded that ATV/r maintenance monotherapy could be a valuable option in a subset of HIV patients, though no predictors of failure were identified.

The ATARITMO study ${ }^{31}$ tried to determine the feasibility of boosted ATV maintenance monotherapy, along with its effects on viral replication, in compartments other than plasma; for example, in the cerebrospinal fluid and semen. At week 24, 3 of 20 patients had detectable viral load in those compartments, despite viral suppression in plasma. As already mentioned, the general perception nowadays is that PI monotherapy must not be considered as an acceptable optional strategy when any other modality of triple antiretroviral regimen can be afforded.

\section{Safety and tolerability}

ATV is generally well tolerated, as shown by the fact that only $5 \%-10 \%$ of patients discontinued the drug due to adverse events in the main register trials. ${ }^{1}$ Indirect bilirubin elevation is the most frequent side effect reported, which is frequently seen within the first months on ATV therapy and tend to slightly decline thereafter due to metabolic compensation mechanisms. This laboratory abnormality only achieves clinical relevance (grade 3-4) in up to one third of patients across studies. Jaundice is infrequent $(<10 \%)$ and causes ATV discontinuation very rarely (around 1\% of treated patients). Bilirubin levels seem to be directly associated to plasma concentrations of ATV; thus, it is more frequent when the drug is boosted with RTV. Of note, hyperbilirubinemia is completely reversible after stopping ATV. Patients with Gilbert's disease or hemolytic anemia 
caused by thalassemia or ribavirin treatment for hepatitis $\mathrm{C}$ experience jaundice more frequently when treated with ATV. ${ }^{32}$ Grade 3-4 elevations in transaminases have been observed in 3\%-14\% of patients receiving ATV. Liver enzyme elevations do not correlate with increased serum bilirubin, and are more frequently seen in HIV subjects with underlying chronic hepatitis B or C. In the AI424-007 study, ${ }^{16}$ in which ATV was given in combination with didanosine and stavudine, grade 3-4 elevations in transaminases occurred in $20 \%$ of patients with chronic hepatitis B and in $40 \%$ of patients with chronic hepatitis $\mathrm{C}$, but in $<10 \%$ of HIV-monoinfected individuals. In studies AI424-008 17 and AI424-034, ${ }^{18}$ ALT levels $>5$ times the upper limit of normality were seen respectively in $15 \%, 14 \%$ and $17 \%$ of seropositive patients for hepatitis B or C treated with ATV, EFV, and nelfinavir. In study AI424-045, ${ }^{26} 20$ patients treated with ATV/RTV and 18 with LPV/RTV, all seropositive for hepatitis B and/or C, experienced increases in ALT levels $>5$ times the upper limit of normality in $25 \%$ and $6 \%$ of cases, respectively. Therefore, liver function tests should periodically be monitored in patients on ATV with underlying chronic liver disease.

Patients on ATV may occasionally complain of gastrointestinal disturbances, although symptoms are generally mild. In the AI424-007 ${ }^{17}$ study, grade 3-4 nausea/vomiting, abdominal pain, or diarrhea occurred in only $2 \%-3 \%$ of patients. Of note, these side effects do not seem to rise when ATV is boosted with RTV. Indeed, in the AI424-045 28 the incidence of grade 2-4 gastrointestinal symptoms was 3\% in the ATV/RTV arm but was much higher in the LPV/RTV $\operatorname{arm}(11 \%)$.

ATV has been shown to prolong the PR interval in electrocardiograms performed on healthy volunteers as well as in HIV-infected patients. ${ }^{33}$ This adversity was not originally reported during the clinical development of the drug and has only rarely been noticed in the post-marketing period. ${ }^{34}$ Abnormalities in atrioventricular conduction are generally asymptomatic, concentration-dependent and limited to first-degree atrioventricular block. Anecdotal reports of second-degree atrioventricular block and other conduction abnormalities have been published. A retrospective analysis of patients enrolled in the ATV expanded access programme (AI424-900 study ${ }^{35}$ ) has shown that QRS intervals increased by a median of $5 \mathrm{~ms}$ in $75 \%$ of antiretroviral-experienced patients, using either boosted or unboosted ATV. The PR and the QTc intervals did not change significantly. According to pooled data from the manufacturer's prescribing information, the incidence of QTc interval prolongation in a total of 1,793 patients treated with ATV was comparable to that of patients receiving other PIs, with none of the patients showing a QTc interval $>500 \mathrm{~ms}$. An additive effect of ATV and drugs that prolong the PR interval (eg, beta-blockers, verapamil, digoxin) and the QT interval cannot be excluded. Hence, when possible these combinations should be avoided. Though very rare, these findings could support periodically performing electrocardiogram monitoring in patients treated with ATV, particularly when boosted with RTV.

Unlike other PIs, ATV seems to have a favorable metabolic profile, namely regarding lipid abnormalities and insulin resistance. ${ }^{36}$

Nephrolithiasis has also been rarely related with ATV exposure, ${ }^{37}$ cause by precipitation of the active principle in the urinary tract. In one retrospective study the prevalence of ATV-associated urolithiasis was $0.97 \% .{ }^{38}$ Patients with low water intake, high urinary $\mathrm{pH}$, and prior history of urinary stones are at higher risk for ATV-associated urine crystallization.

\section{Conclusions}

ATV is an antiretroviral drug that provides a well proven antiviral efficacy, high genetic barrier, low daily pill burden, as well as a more friendly metabolic profile than previous PI. Although ATV is one of the most recently developed PI, there is already strong evidence available for allowing the inclusion of ATV in most guidelines as a preferred regimen. DHHS guidelines include once-daily ATV/r as one of the preferred regimens in combination with emtricitabine (FTC) and tenofovir (TDF) as nucleoside analog backbone. ATV/r can also be combined with abacavir (ABC) or zidovudine (AZT) plus lamivudine (3TC), in what has been considered an alternative regimen. Unboosted ATV can be used in combination with ABC or AZT plus $3 \mathrm{TC}$ in cases when RTV boosting is not posssible. The 2009 European AIDS Clinical Society Guidelines consider $\mathrm{ATV} / \mathrm{r}$ as a recommended regimen when combined with either FTC plus TDF or ABC plus 3TC.

Available evidence supports the widespread use of ATV as base for HAART regimens both in treatment-naïve or pretreated patients. Though having been available since 2003, there is enough data from lengthy trials confirming ATV as an efficacious antiretroviral, with a high genetic barrier and a rather friendly metabolic profile. Its favorable safety profile, low daily pill burden and the once-daily administration favors a high adherence to ATV-containing HAART regimens, making ATV a very interesting drug for HIV treatment. 


\section{Disclosure}

The authors declare no conflicts of interest.

\section{References}

1. Fernandez-Montero JV, Barreiro P, Soriano V. HIV protease inhibitors: recent clinical trials and recommendations on use. Expert Opin Pharmacother. 2010;10:1615-1629.

2. Bristol-Myers Squibb Company. Princeton, NJ 08543, USA. Reyataz product information. Accessed 15 Apr 2010. Available from: http:// packageinserts.bms.com/pi/pi_reyataz.pdf

3. Colonno R, Thiry A, Limoli K, Parkin N. Activities of atazanavir (BMS-232632) against a large panel of HIV type 1 clinical isolates resistant to one or more approved protease inhibitors. Antimicrob Agents Chemother. 2003;47:1324-1333.

4. Drusano G, Bilello J, Preston S, et al. Hollow-fiber unit evaluation of a new HIV type 1 protease inhibitor, BMS-232632, for determination of the linked pharmacodynamic variable. $J$ Infect Dis. 2001;183: 1126-1129.

5. O’Mara E, Mummaneni V, Randall D, et al. BMS-232632: a summary of multiple dose pharmacokinetic, food effect and drug interaction studies in healthy subjects. 7th Conference on Retrovirus and Opportunistic Infections. Jan 3 - Feb 4, 2000. San Francisco, CA, (Abstract 504).

6. McCabe SM, Ma Q, Slish JC, et al. Antiretroviral therapy: pharmacokinetic considerations in patients with renal or hepatic impairment. Clin Pharmacokinet. 2008;47(3):153-172.

7. Rivas P, Morello J, Garrido C, Rodríguez-Nóvoa S, Soriano V. Role of atazanavir in the treatment of HIV infection. Ther Clin Risk Manag. 2009;5:1-18.

8. Colombo S, Buclin T, Cavassini M, et al. Population pharmacokinetics of atazanavir in patients with HIV infection. Antimicrob Agents Chemother. 2006;50:3801-3808.

9. Rutstein R, Samson P, Kiser J, et al. The PATCG 1020 protocol: Atazanavir with or without ritonavir in HIV-infected infants, children, and adolescents. 14th Conference on Retroviruses and Opportunistic Infections. Feb 3-5, 2007. Los Angeles, CA (Abstract 715).

10. Barreiro P, Rodriguez-Novoa S, Labarga P, et al. Influence of liver fibrosis stage on plasma levels of antiretroviral drugs in HIVinfected patients with chronic hepatitis C. J Infect Dis. 2007;195: 973-979.

11. Eley T, Vandeloise E, Child M, et al. Steady state pharmacokinetics and safety of atazanavir after treatment with ATV $300 \mathrm{mg}$ once daily/Ritonavir $100 \mathrm{mg}$ once daily $+\mathrm{ZDV} / 3 \mathrm{TC}$ during the third trimester in HIV+ women. 15th Conference on Retroviruses and Opportunistic Infections. Feb 3-6, 2008. Boston, MA (Abstract 624).

12. Ferreira C, Floch-Tudal C, Meier F, et al. Atazanavir in pregnancy: Influence on neonatal hyperbilirubinemia. 15th Conference on Retroviruses and Opportunistic Infections. Feb 3-6, 2008. Boston, MA (Abstract 625).

13. Mirochnick M, Capparelli E. Pharmacokinetics of antiretrovirals in pregnant women. Clin Pharmacokinet. 2004;43:1071-1087.

14. Panel on Antiretroviral Guidelines for Adults and Adolescents. Guidelines for the use of antiretroviral agents in HIV-1-infected adults and adolescents. Department of Health and Human Services. Dec 1, 2009;1-161. Accessed Apr 5, 2010. Available at http://www.aidsinfo. nih.gov/ContentFiles/AdultandAdolescentGL.pdf

15. Perloff E, Duan S, Skolnik P, et al. Atazanavir: effects on P-glycoprotein transport and CYP3A metabolism in vitro. Drug Metab Dispos. 2005; 33:764-770.

16. Sanne I, Piliero P, Squires K, et al. Results of a phase 2 clinical trial at 48 weeks (AI424-007): a dose-ranging, safety, and efficacy comparative trial of atazanavir at three doses in combination with didanosine and stavudine in antiretroviral-naïve subjects. J Acquir Immune Defic Syndr. 2003;32:18-29.
17. Murphy R, Sanne I, Cahn P, et al. Dose-ranging, randomized, clinical trial of atazanavir with lamivudine and stavudine in antiretroviral-naïve subjects: 48-week results. AIDS. 2003;17:2603-2614.

18. Squires K, Lazzarin A, Gatell JM, et al. Comparison of once-daily atazanavir with efavirenz, each in combination with fixed-dose ZDV and lamivudine, as initial therapy for patients infected with HIV. J Acquir Immune Defic Syndr. 2004;36:1011-1019.

19. Malan D, Krantz E, David N, et al. Efficacy and safety of atazanavir, with or without ritonavir, as part of once-daily highly active antiretroviral therapy regimens in antiretroviral-naïve patients. J Acquir Immune Defic Syndr. 2008;47:161-167.

20. Molina JM, Andrade-Villanueva J, Echevarria J, et al. Once-daily atazanavir/ritonavir versus twice-daily lopinavir/ritonavir, each in combination with tenofovir and emtricitabine, for management of antiretroviral-naïve HIV-1-infected patients: 48 week efficacy and safety results of the CASTLE study. Lancet. 2008;372:646-655.

21. Molina JM, Andrade-Villanueva J, Echevarria J, et al. Once-daily atazanavir/ritonavir compared with twice-daily lopinavir/ritonavir, each in combination with tenofovir and emtricitabine, for management of antiretroviral-naive HIV-1-infected patients: 96-week efficacy and safety results of the CASTLE study. J Acquir Immune Defic Syndr. 2010;53:323-332.

22. Daar ES, Tierney C, Fischl M, et al. ACTG 5202: Final results of $\mathrm{ABC} / 3 \mathrm{TC}$ or TDF/FTC with either EFV or ATV/r in treatment-naïve HIV-infected patients. 17th Conference on Retrovirus and Opportunistic Infections. Feb 16-19, 2010. San Francisco, CA. (Abstract 59LB).

23. Soriano V, de Rossi L. A review of the atazanavir, ritonavir, tenofovir, emtricitabine and nevirapine trial. Eur Infect Dis. 2010. (In press).

24. Haas D, Zala C, Schrader S, et al. Therapy with atazanavir plus saquinavir in patients failing highly active antiretroviral therapy: a randomized comparative pilot trial. AIDS. 2003;17:1339-1349.

25. Cohen C, Nieto-Cisneros L, Zala C, et al. Comparison of atazanavir with lopinavir/ritonavir in patients with prior protease inhibitor failure: a randomized multinational trial. Curr Med Res Opin. 2005;21:1683-1692.

26. Johnson M, Grinsztejn B, Rodriguez C, et al. Atazanavir plus ritonavir or saquinavir, and lopinavir/ritonavir in patients experiencing multiple virological failures. AIDS. 2005;19:685-694.

27. Johnson M, Grinsztejn B, Rodriguez C, et al. 96-week comparison of once-daily atazanavir/ritonavir and twice-daily lopinavir/ritonavir in patients with multiple virologic failures. AIDS. 2006;20:711-718.

28. Soriano V, García-Gasco P, Vispo E, et al. Efficacy and safety of replacing lopinavir with atazanavir in HIV-infected patients with undetectable plasma viraemia: final results of the SLOAT trial. J Antimicrob Chemother. 2008;61:200-205.

29. Gatell J, Salmon-Ceron D, Lazzarin A, et al. Efficacy and safety of atazanavir-based highly active antiretroviral therapy in patients with virologic suppression switched from a stable, boosted or unboosted protease inhibitor treatment regimen: the SWAN Study (AI424-097) 48-week results. Clin Infect Dis. 2007;44:1484-1492.

30. Swindells S, DiRienzo AG, Wilkin T, et al. Regimen simplification to atazanavir-ritonavir alone as maintenance antiretroviral therapy after sustained virologic suppression. JAMA. 2006;296:806-814.

31. Vernazza P, Daneel S, Schiffer V, et al. The role of compartment penetration in PI-monotherapy: the atazanavir-ritonavir monomaintenance (ATARITMO) trial. AIDS. 2007;21:1309-1315.

32. Rodriguez-Novoa S, Morello J, Gonzalez M, et al. Increase in serum bilirubin in HIV/hepatitis $\mathrm{C}$ virus coinfected patients on atazanavir therapy following initiation of pegylated interferon and ribavirin. AIDS. 2008;22:2535-2537.

33. Busti A, Tsikouris J, Peeters M, et al. A prospective evaluation of the effect of atazanavir on the QTc interval and QTc dispersion in HIVpositive patients. HIV Med. 2006;7:317-322.

34. Gallagher D, Kieran J, Sheehan G, et al. Ritonavir-boosted atazanavir, methadone, and ventricular tachycardia: 2 case reports. Clin Infect Dis. 2008;47:36-38. 
35. Gianotti N, Guffanti M, Galli L, et al. Electrocardiographic changes in HIV-infected, drug-experienced patients being treated with atazanavir. AIDS. 2007;21:1648-1651.

36. Mobius U, Lubach-Ruitman M, Castro-Frenzel B, et al. Switching to atazanavir improves metabolic disorders in antiretroviral-experienced patients with severe hyperlipidemia. J Acquir Immune Defic Syndr. 2005;39:174-180.

37. Chang H, Pella P. Atazanavir urolithiasis. N Engl J Med. 2006;355: 2158-2159.

38. Couzigou C, Daudon M, Meynard J, et al. Urolithiasis in HIV-positive patients treated with atazanavir. Clin Infect Dis. 2007;45:105-108.
39. Vora S, Marcelin AG, Gunthard H, et al. Clinical validation of atazanavir/ ritonavir genotypic resistance score in protease inhibitor-experienced patients. AIDS. 2006;20(1):35-40.

40. Pellegrin I, Breilh D, Ragnaud JM, et al. Virological responses to atazanavir-ritonavir-based regimens: resistance substitutions score and pharmacokinetic parameters (Reyaphar study). Antivir Ther. 2006; 11(4):421-429.

41. Bertoli A, Santoro MM, Lorenzini P, et al. Different patterns of mutations involved in the genotypic resistance score for atazanavir boosted versus atazanavir unboosted in multiply failing patients. Antivir Ther. 2006; 11 Suppl 1:S99.

\section{Publish your work in this journal}

HIV/AIDS - Research and Palliative Care is an international, peerreviewed open-access journal focusing on advances in research in HIV, its clinical progression and management options including antiviral treatment, palliative care and public healthcare policies to control viral spread. The journal welcomes original research, basic science, clinical \& epidemiological studies, reviews \& evaluations, expert opinion \& commentary, case reports \& extended reports. The manuscript management system is completely online and includes a very quick and fair peer-review system. Visit http://www.dovepress.com/ testimonials.php to read real quotes from published authors.

Submit your manuscript here: http://www.dovepress.com/hivaids---research-and-palliative-care-journal 